Esta publicación cientifica en formato digital es continuidad de la revista impresa ISSN-Versión Impresa 0798-1406 / ISSN-Versión on line 2542-3185Depósito legal pp
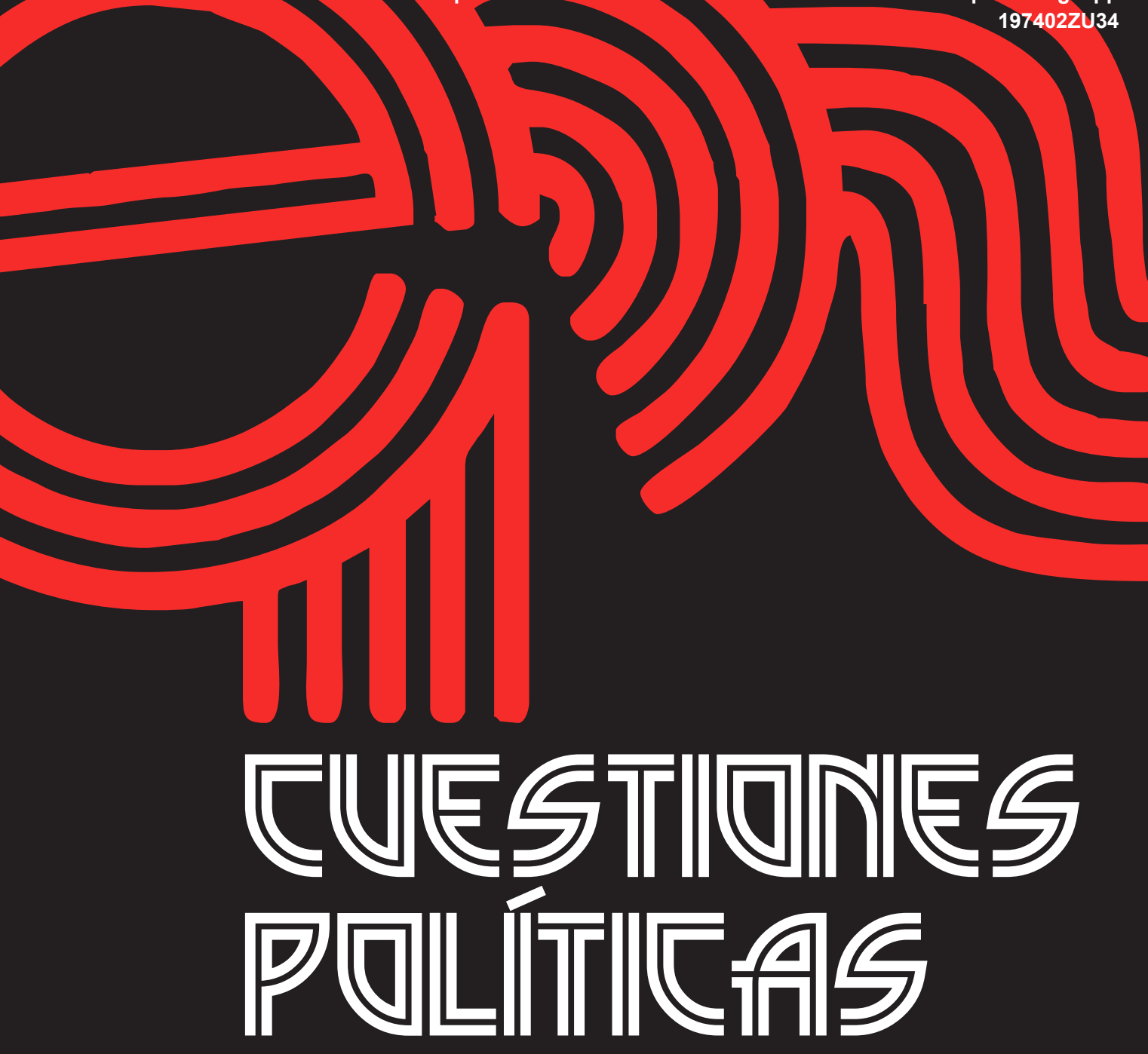

Instituto de Estudios Políticos y Derecho Público "Dr. Humberto J. La Roche" de la Facultad de Ciencias Jurídicas y Políticas de la Universidad del Zulia Maracaibo, Venezuela
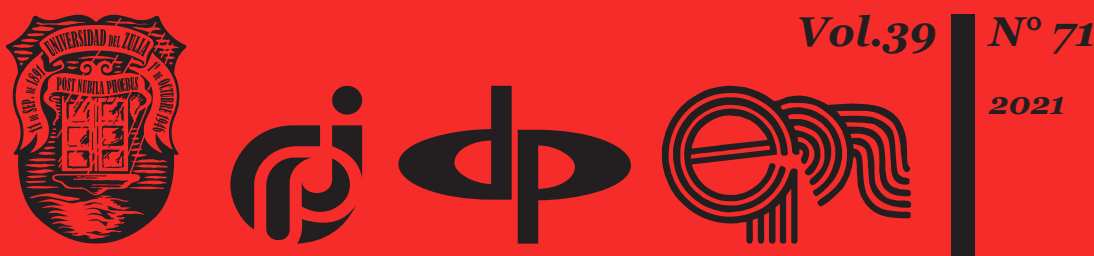


\title{
The military-technical revolution of the XXI st century (Philosophical and analytical review)
}

\author{
DOI: https://doi.org/10.46398/cuestpol.3971.52
}

\author{
Korostylov Hennadii * \\ Olga Dolska ** \\ Dezhong Wang *** \\ Andriy Protsenko **** \\ Yuliia Makieshyna $* * * * *$
}

\begin{abstract}
The article discusses the history of the military-technical revolution, revealing its main characteristics. It was interesting to explain to others theconnection between the revolution and the technical and technological structure ofsociety, on the one hand, and the changes in modern warfare, its timing, the scale of the deployment of hostilities, on the other hand. The study is based on the methodology of systems analysis, as well as the use of logical generalization, synthesis, and abstraction. The authors rely on a wide range of illustrative material, which allowed to show the changes of the sixth military-technological revolution. The nature of the use of unmanned aerial vehicles in modern warfare is considered factual material. Based on specific material, it is argued that the nature of modern warfare is hybrid in nature, but this hybridization itself is heterogeneous. Possible options for waging war and using certain equipment are shown. Based on analytical research, the authors focused on the transformation's characteristic of modern wars. It is concluded that there is a transition period between the sixth and seventh technical-military revolutions that demand future interdisciplinary
\end{abstract} research.

Keywords: military-technical revolution; hybrid warfare; technique; science; unmanned aerial vehicles.

* National Technical University "Kharkiv Polytechnic Institute"; Ukraine. ORCID ID: https://orcid. org/0000-0001-5736-0507

** National Technical University "Kharkiv Polytechnic Institute". Ukraine. ORCID ID: https://orcid. org/0000-0002-9577-8282

*** Deputy Director, International Exchange and Cooperation Department, Jiamusi University, P.R. China. ORCID ID: https://orcid.org/oooo-0002-7014-3627

****BBogdan Khmelnitsky Melitopol State Pedagogical University. ORCID ID: https://orcid.org/oooo0002-9092-7015

***** Prydniprovsk State Academy of Physical Culture and Sport, Ukraine. ORCID ID: https://orcid. org/o0oo-0002-2879-2930 


\section{La revolución militar-técnica del siglo XXI (revisión filosófica y analítica)}

\section{Resumen}

El artículo discute la historia de la revolución técnico-militar, develando sus principales características. Interesó explicar a demás la conexión entre la revolución y la estructura técnica y tecnológica de la sociedad, por un lado, y los cambios en la naturaleza de la guerra moderna, su momento, la escala del despliegue de las hostilidades, por otro lado. El estudio se basa en la metodología de análisis de sistemas, así como en el uso de la generalización lógica, síntesis y abstracción. Los autores se apoyan en una amplia gama de material ilustrativo, que permitió mostrar los cambios de la sexta revolución tecnológico-militar. La naturaleza del uso de vehículos aéreos no tripulados en la guerra moderna se considera material fáctico. Basado en material específico, se argumenta que la naturaleza de la guerra moderna es de naturaleza híbrida, pero esta hibridación en sí misma es heterogénea. Se muestran posibles opciones para hacer la guerra y usar ciertos equipos. Basados en la investigación analítica, los autores se centraron en las transformaciones características de las guerras modernas. Se concluye que hay un período de transición entre la sexta y séptima revoluciones técnicomilitar que demanda de futuras investigaciones interdisciplinarias.

Palabras clave: revolución técnico-militar; guerra híbrida; técnica; ciencia; vehículos aéreos no tripulados.

\section{Introducción}

At the beginning of the XXI century. the term military-technical revolution has been increasingly used. The Revolution in Military Affairs was first written about by M. Roberts. studying in the 1950 os the fundamental changes in the European way of warfare, which were caused by the use of firearms, he actively began to refer to this term (Roberts, 1967). According to E.A. Cohen:

American military experts have been forecasting revolutionary changes in the warfare nature for the past decades. Sometimes these changes are spoken about as military technical revolution. Such a revolution will be the beginning of a fundamental restructuring of the defense system and this will lead to a reduction in the armed forces, a transition to new forms of their organization, revision of the existing army structure and investment of unprecedentedly large funds in research and design development (Cohen, 2005: $\mathrm{s} / \mathrm{p}$ ).

The characteristic features of the military-technological revolution, which is always in coherent development according to the technical- 
technological mode of society, are given. It justifies the thesis of the obvious transitional period between the sixth and seventh military-technological revolutions, emphasizing the high-tech and informational nature of the latter.

\section{Methodology}

The focus was on the system analysis methodology, the national defense system of any state is a complex system that is constantly developing, relying on the scientific achievements, industrial potential, political national ideas and international documents of legal and ethical nature. Since we are talking about the modern military-technical revolution and technological order, the system analysis itself will be based on the causeeffect relationship principle. This will be necessary because the very process of conducting military operations must be seen as open to all changes and unexpected factors, indicates the need to consider the unexpectedness events. This aspect requires consideration of explanation models, both linear and nonlinear, drawing on various forms of causality.

We actively use the methodology of M. Kondratiev about the «economic mode» of development of any country, the world and the methodology of L. Grinin, who adapted this idea to describe the state of science and technology on a global scale. We also take the development of M. Trebin, which actively applies the term "sixth-generation wars», which emphasizes the nature of wars and the ways by which they are organized modern warfare methods. We also fix the transition from mechanization to informatization in the organization of the weapons nature and military actions, that is why we strengthen our reconnaissance with A. Dolskaya's methodology of humanity entry into the third intellectual revolution period, where the emphasis is placed on intellectualization, informatization and mediatization.

The next line should be the methodology of strengthening the technical and technological nature of modern society, because it is the latter has become an indicator of the development and military position of the countries of the world. A significant contribution to the development of this methodology was made by the famous American political scientist Zb Brzezinski: «Post-industrial society becomes a technotronic society - a society which in cultural, social and economic relations is formed under the influence of technology and electronics, general informatization, which is especially developed in the computer and communications field» (Brzezinski, 2005: 6). It is important to understand that the military technology development is subordinate to the general development of science, technology, technology in their complex subordination and cannot be detached from the nature of social development. 
We cannot ignore the methodology proposed by T. Kuhn about the nature of the scientific revolutions development, their connection with scientific rationality, which also affects the technological transformations: «the scientific and technological revolution is a narrower concept, and it is a form of STP, when it takes an accelerated, leapfrog character» (Kuhn, 1974: 650). The military-technical revolution is a radical restructuring of the whole technical and technological production base, which are carried out on the basis of the practical use of the fundamental achievements of modern science.

M. Heidegger's methodology provides an opportunity to embark on a comprehension process of the essence of technology, man and the world in general, emphasizing the broken consciousness whose beginnings are already present in attempts to reflect on the events that humanity experienced after the First World War. That is why the methodology of M. Heidegger with his idea of the correlation between the man and technology development with the man's need to constantly improve it is relevant here, " technique is connected with the fundamental features of man's existence in the world " (Heidegger, 2013: 460). Modern technique, according to M. Heidegger, reveals the essence of the hidden being in nature, placing, ordering everything in order to bring out the unhidden. This kind of interaction with hidden being is the marker of the modern age, and this aggressive kind of disclosure with respect to secret being brings the danger of turning man himself into a technical device, into a function.

\section{Results and discussion}

In our opinion, military revolutions are closely tied to the so-called technological modes. This term was actively used by N.D. Kondratiev, and today it is implemented in analytical reconnaissance by L.Y. Grinin: «Technological modes (TM) are a set of technologies that are typical for production development, a set of connected productions having a single technological level developing synchronously» (Grinin, 2015: 182). We can say that each stage of MTR, each generation of warfare corresponds to a certain technological mode (TM).

In our opinion, modern wars organically fit into the 6th technological paradigm with the characteristic development of science, techniques and technologies, which are the result of a new stage of science and technology development - the so-called NBIC-technology paradigm. This is evidenced by the state of modern warfare, warfare conditions, the use in modern wars the newest weaponry, which is formed due to informatization (the use of ITtechnologies, compliance with the intellectual shift in the form of intellectual revolutions, robotization processes, etc.). Moreover, the development and 
implementation of innovative technologies in the military affairs gives impetus to the development of general science, technology, economy, industry, productive forces, employment of able-bodied population, leads to the withdrawal of the country to a higher stage of development (Schwab, 2017).

Analyzing the wars of the first quarter of the 21st century we record two types of wars: contact wars (4th generation using conventional weapons) and non-contact wars (6th generation using precision weapons on new physical principles, informatization of weapons, forces and means of electronic warfare (Slipchenko, 2002). It should be noted that we do not consider the wars of $5^{\text {th }}$ generation in this article because they are wars using nuclear weapons. The wars of 6th generation cardinally differ from the 4th generation also in that all power of the aggressor is functionally directed mainly to the defeat of the enemy's troops and economy by simultaneous powerful information and high-precision strikes of various weapons (Slipchenko, 2002). Along with contact wars the current numerous combined arms units of ground forces will gradually begin to disappear, and not only nuclear weapons, but also conventional armed forces will finally depreciate.

Maybut wars will widely use weapons based on new physical principles, such as geophysical, radiological, radiofrequency, laser, infrasound, psychotronic, genetic, acoustic, electromagnetic and others (Slipchenko, 2002), i.e. the reduction, minimization of the number of troops involved in an armed conflict, localization of armed conflicts (the transition to the 6th generation war is considered to be the date of the use of guided air bombs by the American military in Vietnam in 1967).

The wars of the 6th generation are commonly referred to as «information wars». In practice, the transition to an «information society» leads to increased opportunities to use methods of economic-information confrontation to strengthen and improve methods of information warfare (Trebin, 2005). For example, the Gulf War «Desert Storm», which lasted five weeks - from January to February 1991, was called the first information war (Colins, 2019). The wars in Yugoslavia (1998), and more recently in Syria (2015) (Sherlock, Homsi, Neuman, 2021) and Karabakh (2020) also fit this characteristic (Gall, 2020). The main characteristics of some 6th generation wars are provided in Table 1. 
CUESTIONES POLÍTICAS

Vol. $39 \mathrm{~N}^{\circ} 71$ (2021): 858-870

\section{Tab. $\mathrm{N}^{\mathrm{o}}$ 1.Comparative characteristics of the 6 th generation} wars

\begin{tabular}{|c|c|c|c|c|}
\hline $\begin{array}{l}\text { No } \\
\mathrm{n} / \mathrm{n}\end{array}$ & $\begin{array}{l}\text { The name } \\
\text { of the war }\end{array}$ & $\begin{array}{l}\text { total time } \\
\text { active } \\
\text { operational } \\
\text { phase }\end{array}$ & $\begin{array}{l}\text { Type of war } \\
\text { (generation) }\end{array}$ & $\begin{array}{c}\text { New types of } \\
\text { weapons, communications, navigation }\end{array}$ \\
\hline 1. & $\begin{array}{l}\text { The war in } \\
\text { the Persian } \\
\text { Gulf. }\end{array}$ & $\begin{array}{l}\text { 17.01.91- } \\
-28.02 .91 \\
\text { (41 days) }\end{array}$ & $\begin{array}{l}\text { VI-th (with } \\
\text { Elemmi } \\
\text { IV-th) }\end{array}$ & $\begin{array}{l}\text { Used more than } 2,000 \text { guided bombs, } \\
\text { only } 10 \% \text { successful launches of guided } \\
\text { missiles and high-precision weapons, } \\
\text { use of new types of communication, } \\
\text { navigation }\end{array}$ \\
\hline 2. & $\begin{array}{l}\text { NATO } \\
\text { operation }\end{array}$ & $\begin{array}{l}23.07 .93^{-} \\
\text {o3.09.93 } \\
\text { (43 days) }\end{array}$ & $\begin{array}{l}\text { VI-th (with } \\
\text { Elemmi } \\
\text { IV-th) }\end{array}$ & $\begin{array}{l}\text { Used } 15,000 \text { precision weapons, the } \\
\text { total percentage of precision targeting } \\
\text { increases to 50-60\%, point attacks } \\
\text { on command and control points and } \\
\text { communications predominate }\end{array}$ \\
\hline 3. & $\begin{array}{l}\text { "Desert } \\
\text { Storm". }\end{array}$ & $\begin{array}{l}20.03 .03 \\
15.04 .03 \\
\text { (27 days) }\end{array}$ & $\begin{array}{l}\text { VI-ro (with } \\
\text { Elemmi } \\
\text { IV-ro) }\end{array}$ & $\begin{array}{l}\text { Used more than } 250 \text { samples of high- } \\
\text { precision weapons, } 80 \% \text { of successful } \\
\text { launches of guided missiles and high- } \\
\text { precision weapons, the use of a new } \\
\text { generation of communication, targeting, } \\
\text { navigation }\end{array}$ \\
\hline 4. & $\begin{array}{l}\text { The war in } \\
\text { Yugoslavia. }\end{array}$ & $\begin{array}{l}30.09 .15 \\
11.12 .17 \\
(2 \text { years } \\
73 \text { days })\end{array}$ & $\begin{array}{l}\text { VI-го (with } \\
\text { Elemmi } \\
\text { IV-го) }\end{array}$ & $\begin{array}{l}\text { Use as armored vehicles samples of the } \\
21 \text { st century, the newest aircraft models } \\
\text { of the 5th-6th generations, antiaircraft } \\
\text { defense, fundamentally new electronic } \\
\text { warfare means, communication }\end{array}$ \\
\hline 5. & $\begin{array}{l}\text { NATO } \\
\text { operation }\end{array}$ & $\begin{array}{l}27.09 .20 \\
10.11 .20 \\
\text { (45 days) }\end{array}$ & $\begin{array}{l}\text { VI-го (with } \\
\text { Elemmi } \\
\text { IV-ro) }\end{array}$ & $\begin{array}{l}\text { Active employment of unmanned aerial } \\
\text { vehicles (Bayraktar, Heron, Hermes } \\
\text { 4507), high-precision weapons (Sky } \\
\text { Stiker, Hagor) }\end{array}$ \\
\hline
\end{tabular}

Source: systematized by the autor.

Considering this table, we can see that the active phase of recent military conflicts is reduced in time, and as a rule, it does NOT lead to the deployment of conflicts in other territory, but the narrowing of the geographical criterion. The wars are becoming localized, the use of high-precision weapons is increasing, and the defeat is primarily aimed at destroying command and control centers, troop concentrations and large military facilities. There is an active use of drones not only for reconnaissance purposes, but the drones are also becoming automated weapons, and the army is turning to "smart weapons,» which minimizes civilian casualties. The modern army is being rapidly computerized, which also speeds up the commanders' decisionmaking, and this generally affects the timing of combat operations in the direction of a reduction in time (Aksenov, 2020). 
We have come to live in the Hybrid War era. Researchers of hybrid warfare recognize that all major wars have an element of hybridity. Indeed, no war has ever been reduced to the actions of the military on the battlefield; wars have always had at least a political and economic dimension.

The hybrid combination forms were unique. C. von Clausewitz compared the variability of the conditions of warfare to water, which has no form of its own. But the uniqueness of hybrid warfare today is that the usual instruments of hybrid influence on the course and outcome of the war is now joined by the factor of new technologies, the use of the newest means of warfare, which are already moving in their technological indicators from the 6 th to the next - 7th technological paradigm.

Depending on what factors influence on the course of military actions, some or other warfare hybridization characteristics become transparent, making it possible to fix different hybrid warfare characteristics (Hoffman, 2007). Hybrid wars have the character of locality, short in time active phases, which are replaced by protracted armed conflicts, and this, as a consequence, is reflected in the course of the war. That is why its name is «hybrid»: beside the main warring parties, there are also external influence levers - global-political and transnational-economic, which decide their geopolitical interests in conducting a small local war.

In the course of these conflicts a completely new terminology emerged, which traces the trends towards the transition to the next generation of warfare - the 7th: non-contact, contact, asymmetric, information, hybrid warfare; informatization of military affairs, network command systems and de-italization of military control systems; information technology, computer and cyber warfare; robotic systems with artificial intelligence (drones, works, drones) remote defeat with precision weapons; use of nanotechnologies and other means of communication.

In spite of the fact that these terms began to be used in everyday life, it gives us a hint to consider that we are in a transitional stage of military development with new characteristics of precision defeat, miniaturization of means of defeat, minimization of personnel involved in a military conflict. The ontologization of military affairs is shaped by new techniques and technologies and gives us an opportunity to talk about new characteristics of military space.

Today all developed states pay much attention to the creation and financing of military information technologies («technologies of creation of visible and invisible» - hybrid information technologies as one of the elements of technological hybridization of warfare), modern militaryscientific centers, engaged in research in creating modern weapon systems, military robotics, autonomous weapon systems, unmanned systems of air and ground, sea-based, nanobiotechnology in military sphere and so on. 
The use of information technology as an information weapon is considered more promising. The latter are an integral part of high-precision munitions. Therefore, it is reasonable to consider these functional subsystems as information weapons as well. The more we dijetalize troop control systems, immerse ourselves in the world of information technology, the more we become unprotected from intrusion of intruders into our electronic bases and electronic troop control systems as a whole. Information weapons based on software code, so-called «cyber weapons,» are being actively developed. At the Defense One Tech Summit on June 23, 2021, U.S. Deputy Assistant Secretary of Defense for Cybersecurity Mieke Yeoyang said: «We want to convince everyone that the issue of cybersecurity is the most significant and its size is an impediment to the entire Department of Defense» (Vergun, 2021: $\mathrm{n} / \mathrm{p}$ ).

The second characteristic of the changes in the transition to the next phase of warfare should be called the growing nature of cybersecurity. The only existing international legal document in the field of information security today is the European Cyber Convention (ETS No. 185 Budapest, 2001), which provides for the possibility to conduct investigative actions in the information space of another state without notifying its law enforcement authorities.

Back in the mid-200os, at a conference in Washington on the problems of defense against cyberterrorists R. Clark explicitly acknowledged that «electronic Pearl Harbor is not a theory. This is reality. In such a context, information operations against control systems become particularly important.

The most famous organization that deals with the latest military technology is the Defense Advanced Research Projects Agency DARPA (USA). It was established in 1958 during the Cold War. The success of the DARPA phenomenon has led to the creation of counterparts of this organization in other countries. For example, DRDO (India) MAFAT (Israel), SASTIND and SRSC (China), the Research Center «Bureau of Defense Solutions» (Russia), GDA (France) and GARDA (Ukraine).

Above, we have already drawn your attention to the fact that even in the 6th generation wars of the early 21st century robotic systems of various purposes are actively used. With the example of drones and drones, we would like to show how their demand in the weapons market is changing. And this is an indication of what changes are taking place in the nature of combat, warfare in general. As for drones, they, strictly speaking, do not belong to the category of classical robots, because they do not reproduce human activity and cannot function successfully without human intervention.

But, as a rule, they are also counted as robotic systems (Bondareva, 2016). Military work is traditionally one of the most common varieties 
(drones, robot-sappers, robot-sanitation, etc.). Military robotics is a wellfunded industry, as promising military developments can be applied to civilian needs as well. Already there is the question of attempts to equate military robots with inhumane weapons, that is, to subject them to the «Convention on Prohibitions or Restrictions on the Use of Certain Conventional Weapons Which May Be Deemed to Be Excessively Injurious or to Have Indiscriminate Effects» (Convention, Geneva, 1980: n/p).

Public organizations, including The Future Of Life Institute, as well as Human Rights Watch, have advocated their prohibition. The key thesis of these organizations is that uncontrolled military works will cause great harm to the civilian population. The fear is that the provision of artificial intelligence in their design makes it possible for them to be fundamentally out of human control.

Global drone and robot procurement spending is projected to exceed $\$ 200$ billion in 2022 (Daily Comm, 2018). According to research firm Gartner, total global sales of drones (of various purposes) alone have reached 2,200,000. Units in 2016 at a value of $\$ 450,000,000$. U.S. dollars, and as early as 2021, sales of 29 million units worth more than $\$ 12$ billion are planned (Drone market outlook in 2021: industry growth trends, 7 market stats and forecast., 2017).

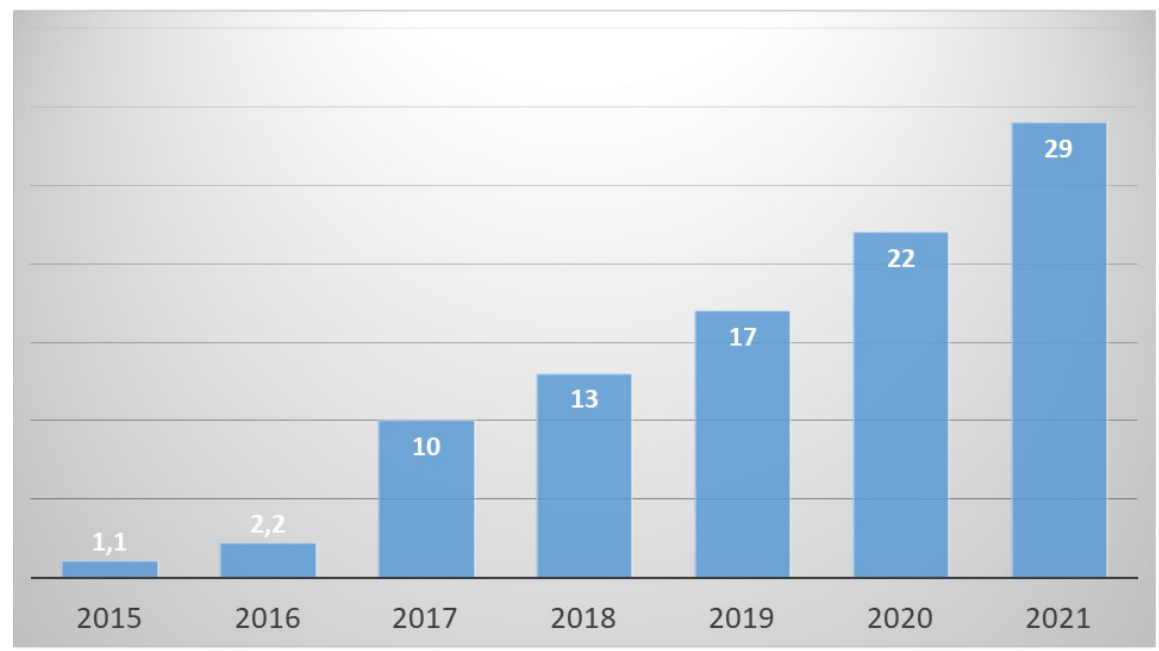

Tab. $\mathbf{N}^{\circ} 2$. Analysis and forecasts of the drone sales market for 2021 (in millions of units). Source: systematized by the author on the basis of statistical data. 
Based on fact analysis, the following modern characteristics of hybrid warfare can be emphasized: miniaturization of weapons; providing weapons with artificial intelligence elements, which means that a favorable outcome of battle can be achieved by using swarms of small drones and drones invisible to enemy radar stations (Cronk, 2021a), rather than using large numbers of armored vehicles and powerful ground forces units. And this next characteristic is to minimize the number of divisions and the total number of troops involved in armed conflicts.

Moreover, as a result of general informatization and growing cybercrime, technologies that once possessed the most powerful armed forces are now in the hands of less capable forces, countries with small armies and even non-state actors, terrorist organizations (it is now no problem to make a flock of drones from cell phone parts or buy a small toy drone from a store) (Cronk, 2021b).

In the development of military affairs, the anthology factor comes out ahead of all qualitative changes. As the technical means of destruction become more complex, as the forms of warfare themselves become more complex (war becomes hybrid, asymmetric), the military's responsibility in decision-making becomes more significant, and around this issue the theme of the human-warrior role in the 7 th generation wars will evolve.

\section{Conclusions}

More and more often scientists refer to the term «military-technical revolution». Each revolution contributes not only to technical and technological transformations in the troops' armament, it will necessarily «stimulate» the transition to a new warfare nature and, as a consequence, will act as a factor through which war will have special characteristics. Today, humanity is dealing with high-tech wars.

This means the next thing. Firstly, today's warfare is conducted in a different information space, where we seethe intertwining of informatization and robotization. Secondly, the use of modern scientific advances in military equipment and technologies leads to changes and transformation of the ontological dimension in military affairs. Thirdly, the abovementioned characteristics are not conclusive, but, in our opinion, allow us making conclusions that mankind is on the verge of transition to the 7 th generation wars, where artificial intellect is in the focus, nanotechnologies are gradually being applied, informatization of troops becomes global and multilevel, penetrates into all military structures, forms new armament samples, digitalizes military management. 
Today wars are most often characterized as hybrid wars, which have their own characteristics in terms of the timing and nature of the weapons used. The latest data provide an opportunity to reach the general characteristics of modern hybrid wars, which include: the growth of information technology, a special attitude to cybersecurity, miniaturization of weapons, providing weapons with artificial intelligence elements, minimization of the number of divisions and the total number of military personnel, the aggravation of the anthropological issue.

\section{Bibliographic References}

AKSENOV, Pavlo. 2020. Drone vijna in Karabakh: how dronelessness changed the conflict between Azerbaijan and Armenia. Available online. In: https://www.bbc.com/russian/features-54431129. Date of consultation: 16/05/2021.

BONDAREVA, Natalia. 2016. State and prospects of development of robotization in the world. Publishing house «MIR», C. 49-57. Moscow, Russia.

BRZEZINSKI, Zbigniew. 2005. Between Two Ages: America's Role in the Technetronic Era/translated from English by I.M. Maksimovoy. Progress Publishing House. Moscow, Russia.

COHEN, ELIOT. 2005. "The military-technical revolution" In: Journal issue. Vol. 26, No. 5. Available online. In: https://strana-oz.ru/2005/5. Date of consultation: 08/05/2021.

COLINS, SHANNON. 2019. Desert Storm: A Look Back. Available online. In: https://www.defense.gov/Explore/Features/story/Article/1728715/ desert-storm-a-look-back/. Date of consultation: 26/05/2021.

CONVENTION ON CYBERCRIME. ETS No. 185 Budapest. 2001. Available online. In: https://zakon.rada.gov.ua/laws/show/994_789\#Text. Date of consultation: 17/05/2021.

CONVENTION ON PROHIBITIONS OR RESTRICTIONS ON THE USE OF CERTAIN CONVENTIONAL WEAPONS WHICH MAY BE DEEMED TO BE EXCESSIVELY INJURIOUS OR TO HAVE INDISCRIMINATE EFFECTS (Geneva). 1980. Available online. In: https://zakon.rada.gov. ua/ laws / show / 995_266 \# Text. Date of consultation: 15/05/2021.

CRONK, Terri Moon. 2021b. DOD Wants Hicks New Artificial Intelligence Initiative. Available online.In: https://www.defense.gov/Explore/News/ Article/Article/2667212/hicks-announces-new-artificial-intelligenceinitiative/. Date of consultation: 26/05/2021. 
CRONK,Terri Moon. 2021a. DOD Wants Partners to Up Their Cybersecurity Game, Official Says. Available online. In: https://www.defense.gov/ Explore/News/Article/Article/2672689/dod-wants-partners-toup-their-cybersecurity-game-official-says/. Date of consultation: 26/05/2021.

DAILY COMM. 2018. In 2022, global spending on buying drones and robots will exceed $\$ 200$ billion. Available online. In: http://www.dailycomm. $\mathrm{ru} / \mathrm{m} / 44324 /$. Date of consultation: 16/05/2021.

DOLSKAYA, Olha. 2015. "Intellectual Revolutions and Thinking Techniques" In: Theory and Practice of Management of Social Systems. Philosophy, Psychology, Pedagogy, Sociology. No. 15, pp. 20-28.

DRONE MARKET OUTLOOK IN 2021: INDUSTRY GROWTH TRENDS, 7 MARKET STATS AND FORECAST. 2017. Available online. In: http:// www.businessinsider.com/drone-industry-analysis-market-trendsgrowth-forecasts-2017-. Date of consultation: 15/05/2021.

GALL, Carlotta. 2020. Roots of War: When Armenia Talked Tough, Azerbaijan Took Action. New York Times. Available online. In: https://www. nytimes.com/2020/10/27/world/europe/armenia-azerbaijan-nagornokarabakh.html. Date of consultation: 16/05/2021.

GRININ, Leonyd; GRININ, Anton. 2015. "The cybernetic revolution and the sixth order” In: Historical Psychology and Sociology of History. №1. 224, pp. 172-197.

HEIDEGGER, Martin. 2013. Being and time. Academic Project Publishing House. Moscow, Russia.

HOFFMAN, Philip. 2007. Conflict in the 21st Century: The Rise of Hybrid War. Potomac Institute for Policy Studies. Arlington, USA.

KUHN, Thomas. 2015. The structure of scientific revolutions. LLC publishing house «AST MOSKVA». Moscow, Russia.

NGO «MILITARY CENTER OF UKRAINE. 2009. War In Yugoslavia. Available online. In: https://mil.in.ua/uk/ulan/. Date of consultation: 16/05/2021.

ROBERTS, Michael. 1967. Essays in Swedish History. Weidenfeld \& Nicolson. London, UK.

SCHWAB, Klaus. 2017. The Fourth Industrial Revolution. AE Publishing House. Moscow, Russia. 
Korostylov Hennadii, Olga Dolska, Dezhong Wang, Andriy Protsenko y Yuliia Makieshyna

870 The military-technical revolution of the XXI st century (Philosophical and analytical review)

SHERLOCK, Ruth; HOMSI, Nada; NEUMAN, Scott. 2021. Syria's Civil War Started A Decade Ago. Here's Where It Stands. Available online. In: https://www.npr.org/2021/o3/15/976352794/syrias-civil-war-starteda-decade-ago-heres-where-it-stands. Date of consultation: 16/05/2021.

SLIPCHENKO, Volodymyr. 2002. War of the Sixth Generation. Weapons and Military Art of the Future. Veche. Moscow, Russia.

TREBIN, Mykhailo. 2004. Army and society: socio-philosophical analysis of interaction in the conditions of transformation. INJEK Publishing House. Kharkiv, Ukraine.

TREBIN, Mykhailo. 2005. Wars of the XXI century. Publishing House AST; Publishing House Harvest. Moscow, Russia.

VERGUN, David. 2021. Leards Discuss Future Warfighting on an Unpredictable Battlespase. Available online. In: https: //www.defense.gov/Explore/ News/Article/Article/2672412/leaders-discuss-future-warfighting-onan-unpredictable-battlespace/. Date of consultation: 16/05/2021. 

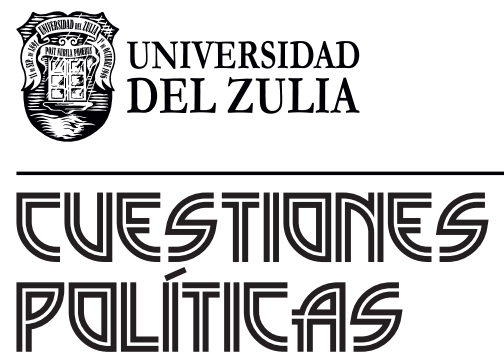

Vol. 39 N $^{\circ} 71$

Esta revista fue editada en formato digital y publicada en diciembre de 2021, por el Fondo Editorial Serbiluz, Universidad del Zulia. Maracaibo-Venezuela 